\title{
Impact of Caring Climate, Job Satisfaction, and Affective Commitment on Employees' Performance in the Banking Sector of Bosnia and Herzegovina
}

\author{
M. Sait DINC ${ }^{*}$, Vesna PLAKALOVIC ${ }^{* *}$
}

\begin{abstract}
The main purpose of this paper is to examine the impact of caring climate, employees' job satisfaction, and affective commitment on employees' job performance in a banking sector. This study proposes that caring climate has a significant direct effect on overall job satisfaction, affective commitment, and job performance. Moreover, it suggests that caring climate has an influence on job performance through overall job satisfaction and affective commitment. Additionally, affective commitment is considered to be a mediator in the relationship between overall job satisfaction and job performance. In this study, the relationships among the variables were evaluated using factor analysis, descriptive statistics, correlations, and regression. The results based on a sample of 152 employees from one public and three private banks in the Federation of Bosnia and Herzegovina support the hypotheses. This study demonstrates that caring climate has a significant direct influence on overall job satisfaction, affective commitment, and job performance. Furthermore, caring climate has an indirect effect on job performance. Finally, this research discovers an indirect relationship between overall job satisfaction and employees' job performance through a mediating role of affective commitment.
\end{abstract}

Keywords: Affective Commitment, Bosnia and Herzegovina, Caring Climate, Job Satisfaction, Job Performance.

JEL Classification Codes: M12, G21, J28, C83

UDC: 331.101.32:[331.101.6:336.71(497.15)]

DOI: https://doi.org/10.17015/ejbe.2016.018.01

\footnotetext{
* Assistant Professor, Department of Management, International Burch University, Bosnia and Herzegovina. E-mail: sdinc@ibu.edu.ba

** International Burch University, Bosnia and Herzegovina. E-mail: vesnaaaplakalovic@hotmail.com 


\section{Introduction}

Employees are the most important human resources in a banking sector. Their performance is directly related to the performance of banks that they work in. While direct contact with customers, monotonous working practices, and heavy paperwork represent some everyday unpleasant obligations of bank tellers, branch managers encounter some stressful challenges, which include responsibility for the overall efficiency and profitability of the branch and managerial issues such as relationship with bank tellers, operations, and credit management. Because of these difficulties, employee shortage and high turnover have been prevalent issues in a banking sector recently. For instance, a human resources director of one of the first national banks in the United States summarizes this problem in a following sentence: "It's not like I'm having mass groups go out to other industries, but it's definitely been on the rise" (Berg, 2014). The situation is similar in the Federation of Bosnia and Herzegovina $(\mathrm{FBiH})$. Based on the report prepared by the Banking Agency of $\mathrm{FBiH}$, which is a regulatory institution that conducts banking supervision, the overall number of employees in banks is reduced by $0.04 \%$ along with a decrease in the number of banks in the last three years (Banking Agency of FBiH, 2016). On the other hand, in contrast to higher average wages in developed countries, the average net wage of employees in 2015 in $\mathrm{BiH}$ has been between USD450 and 475 (Foreign Investment Promotion Agency of $\mathrm{BiH}, 2015$ ). Due to this reason, many bank employees search for jobs with higher salaries. Therefore, the rising annual decrease in the number of employees and employees' desire to change their job sector make an employee shortage in banking sector a very important issue in $\mathrm{FBiH}$. In order to avoid huge employee shortage in this sector in the future, there is a strong need for a research that will find solutions for this issue. At this point, some scholars have suggested examining performance management and workplace behavior of workers and managers in the service sector (Huang \& Bond, 2012).

There are a lot of factors that affect employees' job performance. Nonetheless, job satisfaction (JS) is the factor that is emphasized most frequently (Fu \& Despande, 2013). Most of the scholars have focused on a strong relationship between JS and job performance of the employees (Hira \& Waqas, 2012; Spector, 1997). Trevino, Butterfield, and Mcabe's (1998) study has found that ethical climate plays an important role in developing the context in which the employees operate. Several studies have indicated that among different types of ethical climates, caring climate has a great positive correlation with ethical behavior of employees (Fu \& Deshpande, 2012). On the other hand, JS and organizational commitment are frequently explored together. Some studies have showed that JS has an important effect on organizational commitment (Fu \& Despande, 2013; Huang, You \& Tsai, 2012). However, according to Grdinovac and Yancey's (2012) proposals, employees of organizations that use more caring adaptations have a greater affective organizational commitment than the employees of organizations that use fewer 
Impact of Caring Climate, Job Satisfaction, and Affective Commitment on Employees ...

caring adaptations. While there is an abundance of studies that explore the relationship between employees' JS, organizational commitment, and ethical climate of organizations, literature that focuses on direct and indirect effects of caring climate, overall JS, and affective commitment on the performance of employees is severely limited. In this regard, the purpose of this research is to provide a model for the banking sector in $\mathrm{FBiH}$ (Figure 1). According to aforementioned model, this study examines direct and indirect antecedents of job performance of employees working in public and private banks.

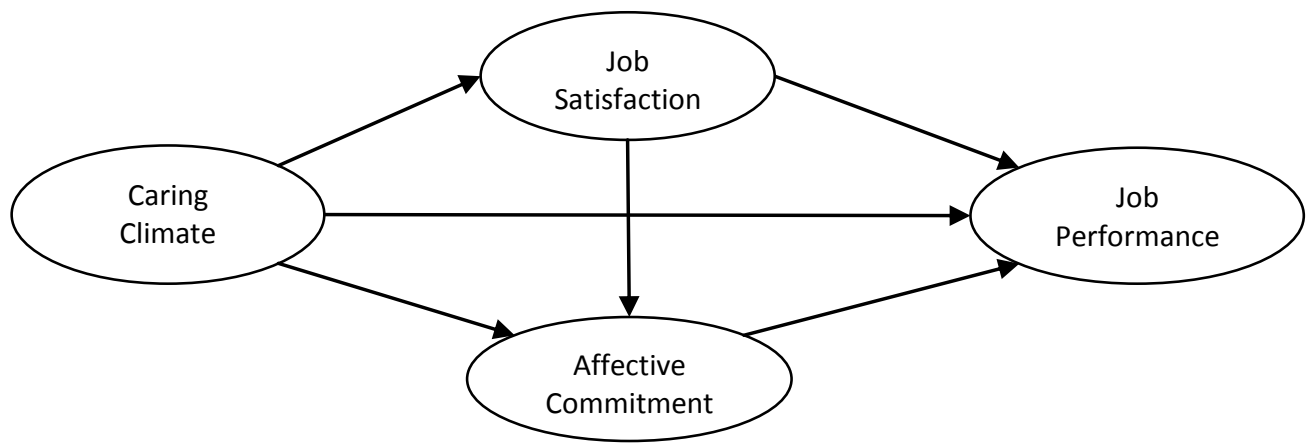

Figure 1. Proposed Research Model

\section{Literature Review}

\subsection{Caring Climate}

Ethical climate is a type of organizational work climate that shapes ethical understanding and behavior of employees within an organization. Victor and Cullen (1988) define it as "prevailing perceptions of typical organizational practices and procedures that have ethical content" (p. 101). In their initial work, Victor and Cullen $(1987,1988)$ categorized ethical climate into five types: caring, independent, law and code, rules, and instrumental. Considering that "caring " climate is one of the most highly rated types of ethical climate among employees, and has the biggest positive correlation with ethical behavior of employees in a study conducted in a Chinese steel company (Fu \& Deshpande, 2012), this research will focus on this climate type as a variable. Caring climate is a type of ethical climate which depends on the concern for others and it is employees' most preferred work climate (Cullen, Parboteeah, \& Victor, 2003). In this type of climate, it is the most important to consider what is best for everyone in the organization. In this atmosphere, employees also have a sincere interest in each other's well-being, as well as in the well-being of others within and outside of the organization who might be influenced by their ethical decisions (Victor \& Cullen, 1987, 1988).

Pevious studies have shown that caring climate has an important effect on employees' job attitudes in their organizations. For example, Deshpande's (1996) research indicated that middle-level managers, who believed that their 
organization had caring climate were more satisfied with their supervisors in a a large non-profit organization. Okpara and Wynn (2008) also found that in Nigerian context caring climate had a significant positive influence on overall JS. Additionally, Dinc and Huric (2016) have shown that "caring" and "rules" climate types have a significant and positive effect on overall JS in a survey of 171 nurses of public and private hospitals in $\mathrm{BiH}$. This research expects that caring climate will significantly impact overall JS of employees of public and private banks and thus proposes the following hypothesis:

Hypothesis 1: Caring climate has a significant direct impact on overall JS.

Recent evidence has demonstrated a positive relationship between ethical climate and organizational commitment (Cullen et al., 2003). However, studies that have concentrated on ehical climate types and organizational commitment components are limited. For instance, Tsai and Huang (2008) found a positive relationship between "caring" and "rules" climate types in Taiwan hospitals and nurses' affective and normative commitment. According to Filipova's (2011) study conducted in Midwestern United States, a caring climate has a significantly positive impact on nurses' organizational commitment. Likewise, in Dinc and Huric's (2016) research, it has been found that "caring" climate and overall job satisfaction significantly affect affective commitment. Therefore, this study proposes the following:

Hypothesis 2: Caring climate has a significant direct impact on affective commitment.

Very little research has been conducted to expore the effect of ethical climate on employees' job performance. Job performance is a work-related outcome that refers to the attainment of organizational objectives measured by evaluating performance on job-related tasks (Sharma, Borna, \& Stearns, 2009). Prior research has focused on the relationship between ethical climate and turnover intentions (Jaramillo, Mulki, \& Solomon., 2006; Mulki, Jaramillo, \& Locander, 2006). In Jaramillo et al.'s (2006) study, the findings showed that a high ethical climate results in a higher job performance of salespeople. Kim and Brymer (2011) also found that ethical leadership of supervisors has an indirect impact on job performance through the mediating role of affective commitment and extra effort. Therefore, this study expects that caring climate also has a significant effect on job performance and proposes the following hypothesis:

Hypothesis 3: Caring climate has a significant direct impact on job performance.

\subsection{Job Satisfaction}

JS is defined as "a pleasurable or positive emotional state resulting from the appraisal of one's job or job experiences" (Locke, 1976, p. 1300). Since the 1930s when the research on JS became popular, job satisfaction has been one of the most frequently studied topics in the organizational behavior field (Jayaratne, 1993). 
Impact of Caring Climate, Job Satisfaction, and Affective Commitment on Employees ...

Several researchers classified job satisfaction into a variety of facets. One of these classifications was done by Smith, Kendall, and Hulin (1969) as follows: satisfaction with pay, satisfaction with promotions, satisfaction with co-workers, satisfaction with the work itself, and satisfaction with supervision. Many studies have examined organizational commitment and JS together and found a positive and significant relationship between these two attitudes of employees (Malik, Nawab, Naeem, \& Danish, 2010; Tsai \& Huang, 2008). In a study conducted by Fu, Deshpande, and Zhao (2011), facets of JS (pay, coworker, supervision, and work itself) had a significant influence on an organizational commitment. Allen and Meyer (1996) also found a positive correlation between JS and affective commitment. On the other hand, some studies have indicated a positive and significant relationship between JS and job performance. For instance, Iqbal, Latif, and Naseer (2012) found that JS has a positive effect on job performance of respondents from different universities. Hira and Waqas (2012) also found a positive relationship between JS and job performance of 335 employees working in a banking sector. Based on the literature above, the study proposes the following two hypotheses:

Hypothesis 4: Overall JS has a significant direct impact on affective commitment.

Hypothesis 5: Overall JS has a significant direct impact on job performance.

\subsection{Affective Commitment}

Organizational commitment is very important for organizations in today's competitive business world, because they are always in need of keeping talented employees. It is a measure of employee's identification with his or her organization (Fu \& Deshpande, 2013). There are several conceptualizations of organizational commitment. The most cited and well-known conceptualization is Meyer and Allen's (1991) three component model. According to their conceptualization, mentioned three components are affective commitment, continuance commitment, and normative commitment. Of the three dimensions of organizational commitment, the positive effect of affective commitment on employee behaviors and performance has received the greatest support by empirical studies (Moorman, Niehoff, \& Organ, 1993; Shore \& Wayne, 1993; Douglas, 1997). Therefore, this study will concentrate on this component of the organizational commitment. Affective commitment is an individual's emotional attachment to the organization. According to Meyer et al. (1993), employees who have a strong affective commitment remain with the organization because they wish to. Many studies have shown a significant and positive correlation between organizational commitment and job performance. For example, a meta-analysis conducted in 14 countries by Jaramillo, Mulki, and Marshall (2005) indicated a strong and positive relationship between organizational commitment and job performance for sales employees. Likewise, in Jamal's (2011) study, it was found that organizational commitment has a significant impact on job performance. Additionally, Meyer and Allen (1997) have argued that both normative commitment and affective commitment will be linked to performance; however, 
affective commitment is more related to it. Thus, this study expects that affective commitment will have a significant effect on employees' job performance and thus proposes the following hypothesis:

Hypothesis 6: Affective commitment has a significant direct impact on job performance.

Some prior studies have examined the mediating effect of job attitudes between several variables. For example, the study shows that the mediating role of JS and organizational commitment has been found between ethical climate and organizational citizenship behavior of 213 employees working in private universities in $\mathrm{BiH}$ (Dinc \& Aydemir, 2014). Fu et al. (2013) also found that caring climate has a significant indirect impact on job performance through the mediating role of JS. Based on the existing literature, this study proposes indirect effect of caring climate on job performance through JS and affective commitment. It also proposes that overall JS has an indirect impact on job performance through affective commitment. Therefore, the following hypotheses were posited:

Hypothesis 7: Caring climate has a significant indirect impact on job performance through the mediating role of JS and affective commitment.

Hypothesis 8: Overall JS has a significant indirect impact on job performance through the mediating role of affective commitment.

\section{Research Method}

\subsection{Sample and Data Collection}

According to the report of the Banking Agency of $\mathrm{FBiH}$ in the period from 2014 to 2016 (Banking Agency of $\mathrm{FBiH}, 2016$ ), the number of public and private banks in FBiH was 17 (Private banks: 16, Public banks: 1). The number of employees in these companies was 6,677. The research focused on the public and private banks in $\mathrm{FBiH}$. In order to enable better generalization of the research results, the study targeted employees working in public and private banks in Sarajevo, the capital of $\mathrm{FBiH}$. 200 questionnaires were distributed in one public and three private banks. A formal research approval was obtained from the administration of each examined bank. Questionnaires were delivered to banks that have agreed to take part in the study. The purpose of the study was explained to encourage employees' voluntary participation, and to guarantee the anonymity of participants. The questionnaires were distributed to employees who agreed to participate in the research. The overall response rate (175 completed questionnaires of which 152 were useful) was $76 \%$.

A summary of the sample characteristics is presented in Table 1. The majority of the respondents (57.2\%) were female, and $82.9 \%$ of these employees were older than 26. The predominant level of education among employees (40.8\%) was bachelor degree. The majority of employee respondents $(77.7 \%)$ had salary of more than 590 USD per month. $70.4 \%$ of the employees' total work experience was more than 6 years. 
Impact of Caring Climate, Job Satisfaction, and Affective Commitment on Employees ...

Table 1. Sample Characteristics

\begin{tabular}{|c|c|c|c|}
\hline Variable & Demographics & Number & Valid Percent (\%) \\
\hline \multirow[t]{2}{*}{ Gender } & Male & 65 & 42.8 \\
\hline & Female & 87 & 57.2 \\
\hline \multirow[t]{6}{*}{ Age } & Under 20 years & 1 & 0.7 \\
\hline & $21-25$ years & 25 & 16.4 \\
\hline & $26-29$ years & 33 & 21.7 \\
\hline & 30-35 years & 32 & 21.1 \\
\hline & $36-39$ years & 26 & 17.1 \\
\hline & Over 40 years & 35 & 23 \\
\hline \multirow[t]{2}{*}{ Marriage } & Yes & 75 & 49.3 \\
\hline & No & 77 & 50.7 \\
\hline \multirow[t]{2}{*}{ Bank Type } & Private & 100 & 65.8 \\
\hline & Public & 52 & 34.2 \\
\hline \multirow[t]{4}{*}{ Tenure in the bank } & Under 5 years & 59 & 38.8 \\
\hline & $6-10$ years & 51 & 33.6 \\
\hline & $11-15$ years & 20 & 13.2 \\
\hline & Over 16 years & 22 & 14.5 \\
\hline \multirow[t]{4}{*}{ Total Tenure } & Under 5 years & 45 & 29.6 \\
\hline & $6-10$ years & 50 & 32.9 \\
\hline & $11-15$ years & 25 & 16.4 \\
\hline & Over 16 years & 32 & 21.1 \\
\hline \multirow[t]{4}{*}{ Education Level } & High school & 16 & 10.5 \\
\hline & Bachelor degree & 62 & 40.8 \\
\hline & Master degree & 49 & 32.2 \\
\hline & Other & 25 & 16.4 \\
\hline \multirow[t]{5}{*}{ Average Wage } & 0 - 295 USD & 5 & 3.3 \\
\hline & 295 - 590 USD & 29 & 19.1 \\
\hline & 590 - 880 USD & 46 & 30.3 \\
\hline & 880 - 1175 USD & 39 & 25.7 \\
\hline & above 1175 USD & 33 & 21.7 \\
\hline \multirow[t]{4}{*}{ Position in the bank } & Director/ Sector Coordinator & 26 & 17.1 \\
\hline & Family Banker & 40 & 26.3 \\
\hline & Bank teller & 32 & 21.1 \\
\hline & Others & 54 & 35.5 \\
\hline
\end{tabular}

\subsection{Instruments and measures}

A three-page questionnaire with five sections was used to collect data. The first section of the questionnaire included questions about job performance. The second section was connected to the overall job satisfaction. The third section of the questionnaire consisted of questions about affective commitment, and the fourth section referred to caring climate. Finally, the last section included demographic questions about participants. Questions such as age group, gender, education, marriage, income, sector of the bank, duration of employment in the company, and employment duration in total were asked in this section. The survey was initially prepared in English and then translated into the Bosnian language. The translation of the questionnaire was realized by experts who are competent in both 
languages and possess knowledge of their respective cultures. Pilot study of the survey was performed with 30 employees of a private bank. The purpose of pilot testing was to assess the validity of the survey. Ambiguous questions were reevaluated and finalized for data collection.

Job performance is measured using three items developed by Fu and Deshpande (2013). Bank employee respondents were asked to rate their own overall performance at work in the last year, report how their boss would rate or has already rated their overall performance at work in the last year, and how their colleagues would rate their overall performance at work in the last year. The questions were measured using a 5 -point Likert scale ( 1 = very poor; 5 = very good). The Cronbach's alpha coefficient for this scale in their study was 0.837 .

JS was measured using three items developed by Fu and Deshpande (2013). They adapted three-item scale from Cellucci and Devries's (1978) job satisfaction scale. These three items were: I frequently think about quitting this job (reverse coded); I am satisfied with the activities I perform every day; Generally speaking, I am very satisfied with this job. These items were measured using a 5-point Likert scale (5 = mostly true; 1 = mostly false). The Cronbach's alpha coefficient for this scale in their study was 0.696 .

Affective commitment was measured using Meyer and Allen's (1997) six-item affective commitment scale. Affective commitment consisted of 6 items. They were: I would be very happy to spend the rest of my career with this organization; I really feel as if this organization's problems are my own; I do not feel a strong sense of belonging to my organization; I do not feel like "part of the family" at my organization (R); I do not feel "emotionally attached" to this organization (R); This organization has a great deal of personal meaning for me. These items were measured using a 5-point Likert scale (5 = strongly agree; 1 = strongly disagree). The Cronbach's alpha coefficient for this scale in their study was higher than 0.60 .

Finally, bank employee respondents completed the three-item caring climate scale developed by Huang, You, and Tsai (2012), who adapted the scale from Victor and Cullen (1988). The items were as following: The most important concern is the good of all the people in the hospital as a whole; What is best for everyone in the hospital is the major consideration here; Our major concern is always what is best for the other person. A 5-point Likert scale (5 = strongly agree; $1=$ strongly disagree) was used to measure caring climate. The Cronbach's alpha coefficient for this scale in their study was 0.813 .

\subsection{Data analysis}

The data were analyzed by using SPSS (v. 20) software packages. Exploratory factor analysis was used to analyze the initial factor structure. Reliability of the scales was measured by using Cronbach's alpha coefficient. General characteristics of participants were summarized after the analysis of descriptive statistics. Pearson's 
Impact of Caring Climate, Job Satisfaction, and Affective Commitment on Employees ...

correlations were used to show the relationships between job performance, overall job satisfaction, affective commitment, and caring climate. Finally, in order to determine direct impact of caring climate on job performance and its indirect effect through overall job satisfaction and affective commitment, regression analyses were used. The results are presented in the following section.

\section{Results}

\subsection{Initial Analyses}

The construct validity of four scales used in the analysis was examined by using the exploratory factor analysis to investigate the initial factor structure (Churchill, 1979). Aforementioned four factors were caring climate, overall job satisfaction, affective commitment, and job performance.

The four scales were analyzed together. The principal component analysis was used as the factor extraction method, and the varimax method was used for the component rotations. In the first run, job satisfaction item 1 was eliminated from further analysis, because it was cross-loaded on two components. Secondly, affective commitment items 1, 2, and 7 were eliminated from further analysis because of their incongruity with the literature. The coefficient alpha for caring climate, affective commitment, overall JS, and job performance was $0.886,0.772$, 0.751 , and 0.754 respectively. Factor loadings and coefficient alpha for these four scales are presented in Table 2.

Table 2. Factor Loadings and Coefficient Alpha for Caring Climate, Affective Commitment, Job Satisfaction, and Job Performance

\begin{tabular}{|c|c|c|}
\hline & $\begin{array}{l}\text { Factor } \\
\text { Loading }\end{array}$ & $\begin{array}{l}\text { Chronbach's } \\
\text { Alpha }\end{array}$ \\
\hline Caring Climate & & 0,886 \\
\hline What is best for everyone in the bank is the major consideration here. & 0,881 & \\
\hline $\begin{array}{l}\text { The most important concern is the good of all the people in the bank as a } \\
\text { whole. }\end{array}$ & 0,844 & \\
\hline Our major concern is always what is best for the other person. & 0,807 & \\
\hline Affective Commitment & & 0,772 \\
\hline I do not feel like part of the family at my bank.* & 0,819 & \\
\hline I do not feel a strong sense of belonging to my bank.* & 0,792 & \\
\hline I do not feel emotionally attached to this bank.* & 0,788 & \\
\hline Job Satisfaction & & 0,751 \\
\hline I am very satisfied with activities I perform on my job position every day. & 0,859 & \\
\hline Generally, I am very satisfied with my current job. & 0,781 & \\
\hline Job Performance & & 0,754 \\
\hline How do you rate your job performance? & 0,828 & \\
\hline How does your supervisor rate your job performance during the last year? & 0,813 & \\
\hline How do your collagues rate your job performance during the last year? & 0,698 & \\
\hline
\end{tabular}

*Items are reverse coded 


\subsection{Descriptive statistics and correlations for components of Caring climate, Affective commitment, Job satisfaction and Job performance}

Table 3 presents the means, standard deviations, and correlations for the variables used in the study. As expected, job performance is significantly correlated with the mediators and independent variable. Respondents identified the presence of job satisfaction (mean $=4.16$ ). It was followed by job performance (mean $=3.67$ ) and affective commitment (mean $=3.65)$. The lowest score among the variables was caring climate (mean $=3.45)$.

\section{Table 3. Mean, Standard Deviations, and Correlations}

\begin{tabular}{lcccccc}
\hline \multicolumn{1}{c}{ Variables } & Mean & SD & 1 & 2 & 3 & 4 \\
\hline (1) Caring Climate & 3,45 & 1,111 & 1 & & & \\
(2) Affective Commitment & 3,65 & 1,084 & $0.387^{* *}$ & 1 & & \\
(3) Job Satisfaction & 4,16 & 0,617 & $0.468^{* *}$ & $0.333^{* *}$ & 1 & \\
(4) Job Performance & 3,67 & 0,919 & $0.414^{* *}$ & $0.297^{* *}$ & $0.328^{* *}$ & 1 \\
\hline
\end{tabular}
$* * \mathrm{P}<0.01$

\subsection{Hypotheses testing}

The first hypothesis stated that caring climate has a significant direct impact on overall JS. Table 4 shows that caring climate significantly and positively affected overall JS. This finding supports the Hypothesis 1 . Second hypothesis stated that caring climate has a significant direct impact on affective commitment. The results in the study show that caring climate positively impacts affective commitment, therefore Hypothesis 2 is supported. The third hypothesis stated that caring climate has a significant direct impact on job performance. The study findings demonstrate that caring climate has a significant and positive influence on job performance. As a result, Hypothesis 3 is supported.

Table 4. Path analysis of the relationship among Caring climate, Overall job satisfaction, Affective commitment, and Job performance

\begin{tabular}{lccc}
\hline \multirow{2}{*}{ Variables } & Overall Job & Affective & Job \\
& Satisfaction & Commitment & Performance \\
\hline Caring Climate & $0,388^{* * *}$ & $0,289^{* * *}$ & $0,163^{* * *}$ \\
Overall Job Satisfaction & & $0,228^{*}$ & 0,098 \\
Affective Commitment & & & 0,077 \\
\hline${ }^{*} \mathrm{P}<0.05 ;{ }^{* * * \mathrm{P}<0.001}$ & & &
\end{tabular}

In the Hypothesis 4, it was stated that overall JS has a significant direct impact on affective commitment. Table 4 demonstrates that overall JS significantly and positively impacted affective commitment. This finding supports Hypothesis 4 . Hypothesis 5 stated that overall JS has a significant direct impact on job performance. The results of the study show that overall JS does not have any direct influence on job performance. Consequently, Hypothesis 5 is not supported. 
Impact of Caring Climate, Job Satisfaction, and Affective Commitment on Employees ...

In testing Hypothesis 6, it was stated that affective commitment has a significant direct impact on job performance. Table 4 indicates that affective commitment does not have any direct effect on job performance. Therefore, Hypothesis 6 is not supported.

In the final path of this study, using regression, Baron and Kenny's (1986) threestep procedure was followed in order to analyze the mediating role of overall JS and affective commitment. First of all, the independent variable should be significantly related to the mediator variable. Secondly, the independent variable should be related to the dependent variable. Finally, the mediating variable should be related to the dependent variable with the independent variable included in the equation. If these three conditions hold, then at least partial mediation is present. If the independent variable has a non-significant coefficient in the third step, then complete mediation is present.

In testing Hypothesis 7, the first mediator (Overall JS) was regressed on the independent variable (Caring climate). As shown in Table 5, the coefficients for caring climate are significant. Thus, the first requirement for the mediation posited in the Hypothesis 7 is satisfied. Next, the dependent variable (job performance) was regressed on the independent variable. To satisfy the second requirement of mediation, the coefficients for caring climate had to be significant. The results from this step of the mediation analysis demonstrate significance for the dependent variable (0.230).

\section{Table 5. Regression Equation Tests for Hypothesis 7 and 8}

\begin{tabular}{lcccc}
\hline & $\begin{array}{c}\text { Equation 1: } \\
\text { Mediator= }\end{array}$ & $\begin{array}{c}\text { Equation 2: } \\
\text { Dependent }\end{array}$ & \multicolumn{2}{c}{ Equation 3: } \\
& $\mathrm{f}$ (Independent) & $\mathrm{f}$ (Independent) & \multicolumn{2}{c}{$\mathrm{f}$ (Independent and Mediator) } \\
\cline { 2 - 5 } & Coefficients for & Coefficients for & Coefficients for & Coefficients \\
& Independent & Independent & Independent & for \\
Models & Variables & Variables & Variables & Mediators \\
& $.388(.469)$ & $.230(.414)$ & $.185(.333)$ & $.116(.172)$ \\
$\mathrm{CC} \rightarrow \mathrm{JS} \rightarrow \mathrm{JP}$ & $(6.49)$ & $(5.56)$ & $(4.00)$ & $(2.07)$ \\
& $.378(.387)$ & $.230(.414)$ & $.195(.352)$ & $.091(.161)$ \\
$\mathrm{CC} \rightarrow \mathrm{AG} \rightarrow \mathrm{JP}$ & $(5.14)$ & $(5.56)$ & $(4.40)$ & $(2.01)$ \\
& $.392(.333)$ & $.220(.328)$ & $.173(.258)$ & $.120(.211)$ \\
$\mathrm{JS} \rightarrow \mathrm{AC} \rightarrow \mathrm{JP}$ & $(4.31)$ & $(4.25)$ & $(3.21)$ & $(2.62)$ \\
& & &
\end{tabular}

Notes: * Not significant at .05 level. Values in the parentheses in the first rows are standardized coefficients. Values in the parentheses in the second rows are t-values. CC: Caring climate; JS: Job satisfaction; AC: Affective commitment; JP: Job performance.

In testing the third condition of mediation, overall JS were regressed on job performance, with caring climate included in the equation. The results, shown in the Table 5, indicate that overall JS partially mediates the relationship between caring climate and job performance, as the coefficients for caring climate decrease after overall JS is added but remain significant (.185). However, the second 
mediator (affective commitment) was regressed on the independent variable (caring climate). The coefficients for caring climate are significant, and this result satisfies the first condition of mediation of the hypothesis. In the second step, the coefficients for caring climate in the regression of the dependent variable (job performance) on caring climate are significant (0.230). In the third step, job performance was regressed on affective commitment with caring climate included in the equation. Caring climate has significant coefficients (0.195), but they decline after affective commitment is added. Thus, affective commitment partially mediates the relationship between caring climate and job performance. Therefore, Hypothesis 7 was partially supported.

In order to test the Hypothesis 8 , affective commitment was the mediator. The coefficients for the independent variable (Overall JS) are significant (0.392). The coefficients for overall JS in the regression of the dependent variable (Job performance) on overall JS are significant (0.220). In the third step of the mediation test, job performance was regressed on overall JS with affective commitment included in the equation. The coefficients for overall JS are significant $(0.173)$ but, its coefficients decrease after affective commitment is added. Therefore, it can be concluded that the mediation posited in Hypothesis 8 partially exists.

\section{Conclusion and Limitations}

Given the importance of job performance in organisations, this study examines the effect of caring climate on job performance through employee attitudes in public and private banks in $\mathrm{FBiH}$. Consistent with the research hypotheses, caring climate has a direct impact on employee attitudes and job performance. Employee attitudes are found to mediate the relationship between caring climate and job performance. The study has also found that affective commitment has mediating effect on the relationship between overall JS and job performance. The study does not find any support for the direct effect of employee attitudes on job performance. The implications of the study are highlighted in the following paragraphs.

In this study, JS is the most highly rated variable in the public and private banks in $\mathrm{FBiH}$. This result may be related to a high unemployment rate $(44.86 \%)$ in $\mathrm{BiH}$ (Trading Economics, 2016; Coskun \& Ilgun, 2009). As it is difficult for employees to find another job, they have to be satisfied with the job that they have at that moment. Bank employees rated their performance very high. These results imply that employees' perception about their performance is good enough. This is consistent with Fu and Deshpande's (2013) findings. The study also shows that one of the highest rated variables is affective commitment. Meyer, Alen, and Smith (1993) stressed that employees who have a strong affective commitment remain with the organization because they want to do so. Thus, this study proposes that managers of the banks should focus on strategies for increasing employees' affective commitment in order to make them emotionally committed to their bank. 
Impact of Caring Climate, Job Satisfaction, and Affective Commitment on Employees ...

This research shows that caring climate is a predictor of a variety of organizational outcomes such as overall JS, affective commitment, and job performance of employees who work in the banks. The impact of caring climate is both direct and indirect. This result is consistent with a previous literature (Fu \& Deshpande, 2013; Dinc \& Huric, 2016). The employees who believed that their banks had a caring climate were overally more satisfied with their job, affectively committed to their organization, and had better job performance. Thus, bank administrations in $\mathrm{FBiH}$ can increase a caring atmosphere and ensure that they are concerned with the well-being of all people in the banks. This research also strongly suggests the need for the improvement of different strategies for strengthening banks' caring climate. The bank administrations should foster caring climate by including the following: codes of ethics, whistle-blowing systems, and ethical training as some exemplary topics of conversation with employees. According to Dale (2005), there are five ways that can also be suggested in order to make employees feel cared about: personal touch, personal follow up, placing personalized remarks in writing, giving public praise, and making frequent contact.

This study found a positive and a direct effect of JS on employees' affective commitment and an indirect impact on job performance. These results are consistent with Alen and Meyer's (1996) and Tsai and Huang's (2008) findings. These findings imply that bank administrators should improve some strategies to enhance JS of their employees. Some studies give several suggestions to increase employees' JS. For example, constructive feedback used by supervisors provides greater JS for employees (Sommer \& Kulkarni, 2012). Another study proposes that a good environment provided by administration for employees' learning is crucial to improve their JS (Alonderiene, 2010). However, bank administrations in $\mathrm{FBiH}$ should increase JS of their employees by increasing their salaries and providing some additional rewards. The banks in $\mathrm{FBiH}$ that can realize these suggestions will be able to enhance employees' JS and make them more committed to their organizations. Thus, employee shortage and high turnover rate in banks in this country will be reduced in a near future.

Although this research helps us better understand JS, affective commitment, and job performance of employees working in banks of $\mathrm{FBiH}$, it has several limitations. First of all, the results in this study are obtained from a limited sample. Surveys with higher sample sizes may yield different results. Secondly, self-reported issue may be another limitation of this research. Final limitation of this research is the insufficient literature. Further research should examine the impact of other types of ethical climate such as rules, independent types, and instrumental types on JS facets, organizational commitment components, and job performance of employees in banks of $\mathrm{FBiH}$. Moreover, future studies should focus on the effect of ethical leadership on employees' JS and organizational commitment components. 


\section{References}

Allen, N. J., \& Meyer, J. P. (1996). Affective, Continuance, and Normative Commitment to the Organization: An Examination of Construct Validity. Journal of Vocational Behavior, 49, 252276. https://doi.org/10.1006/jvbe.1996.0043

Alonderiene, R. (2010). Enhancing informal learning to improve job satisfaction: Perspective of SMEs managers in Lithuania. Baltic Journal of Management, 5(2), 257-287. https://doi.org/10.1108/17465261011045151

Banking Agency of FBiH, (2016, March 31). Information on the Banking System of FBiH. Retrieved on September 26, 2016, from website: http://srv1.fba.ba/images/Publikacije_Banke/Informacija_BS_FBiH_31_03_2016_eng.pdf.

Baron, R.M. \& Kenny, D.A. (1986). The moderator-mediator variable distinction in social psychological research: conceptual, strategic, and statistical considerations. Journal of Personality and Social Psychology, 51, 1173-1182, doi:10.1037/0022- 3514.51.6.1173.

Berg, J. (2014, October 26). What Are the Biggest Human Resources Challenges at Banks? Retrieved on September 22, 2016, from American Banker website: http://www.americanbanker.com/news/community-banking/what-are-the-biggest-humanresources-challenges-at-banks-1070833-1.html.

Churchill, G. A. (1979). A paradigm for developing better measures of marketing constructs. Journal of Marketing Research, 64-73. https://doi.org/10.2307/3150876

Coskun, A., \& Ilgün, E. (2009). Reconstruction and Developments in the Banking Sector of Bosnia and Herzegovina, 1. International Symposium on Sustainable Development, Sarajevo.

Cullen, J. B., Parboteeah, K. P., \& Victor, B. (2003). The effects of ethical climates on organizational commitment: A two-study analysis. Journal of Business Ethics, 46, 127-141.

https://doi.org/10.1023/A:1025089819456

Dale, C. (2005). 5 ways to show employees how much you care: Printing News, 154(20), 16.

Deshpande, S. P. (1996). Ethical climate and the link between success and ethical behavior. An empirical investigation of a non-profit organization. Journal of Business Ethics, 315-320. https://doi.org/10.1007/BF00382957

Douglas, S. B. (1997) Organizational citizenship behavior among hospital employees: a multidimensional analysis involving job satisfaction and organizational commitment. Hospital \& Health Services Administration, 42(2), 221-241.

Dinc, M. S., \& Huric, A. (2016). The impacts of ethical climate types on nurses' behaviors in Bosnia and Herzegovina. Nursing Ethics, 1-14. https://doi.org/10.1177/0969733016638143

Dinc, M. S., \& Aydemir, M. (2014). Ethical leadership and employee behaviours: an empirical study of mediating factors. International Journal of Business Governance and Ethics, 9(3), 293-312. https://doi.org/10.1504/IJBGE.2014.064738

Filipova, A. A. (2011). Relationships among ethical climates, perceived organizational support, and intent-to-leave for licensed nurses in skilled nursing facilities. Journal of Applied Gerontology, 30(1), 44-66. https://doi.org/10.1177/0733464809356546

Foreign Investment Promotion Agency of Bosnia and Herzegovina, (2015, September 18). Retrieved on June 15, 2016, from website: http://www.fipa.gov.ba/publikacije_materijali/brosure/io. 
Impact of Caring Climate, Job Satisfaction, and Affective Commitment on Employees ...

Fu, W., Deshpande, S. P., \& Zhao, X. (2011). The impact of ethical behavior and facets of job satisfaction on organizational commitment of Chinese employees. Journal of Business Ethics, 104, 537-543. https://doi.org/10.1007/s10551-011-0928-4

Fu, W., \& Deshpande, S. P. (2012). Factors impacting ethical behavior in a Chinese stateowned steel company. Journal of Business Ethics, 5, 231-237. https://doi.org/10.1007/s10551-011-0962-2

Fu, W., \& Deshpande, S. P. (2013). The impact of caring climate, Job satisfaction, and Organizational Commitment on Job Performance of Employees in A China's Insurance Company. Journal Business Ethic, 339-349.

Grdinovac, J. A., \& Yancey, J. B. (2012). How organizational adaptations to recession relate to organizational commitment. The Psychologist-Manager Journal, 15, 6-24 https://doi.org/10.1080/10887156.2012.649089

Hira, A., \& Waqas, I. (2012). A Study of job satisfaction and IT's Impact on the performance in the banking industry of Pakistan. International Journal of Business and Social Science, 174180.

Huang, X., \& Bond, M. H. (2012). Handbook of Chinese organizational behavior: Integrating theory, research. Northampton, MA: Edward Elgar Publishing. https://doi.org/10.4337/9780857933409

Huang, C. C., You, C. S., \& Tsai, M.T. (2012). A multidimensional analysis of ethical climate, job satisfaction, organizational commitment, and organizational citizenship behaviors. Nursing Ethics, 19(4), 513-529. https://doi.org/10.1177/0969733011433923

Iqbal, M. T., Latif, W., \& Naseer, W. (2012). The impact of person job fit on job satisfaction and its subsequent impact on employees performance. Mediterranean Journal of Social Sciences, 3(2), 523-530.

Jaramillo, F., Mulki, J. P., \& Marshall, G. W. (2005). A meta-analysis of the relationship between organizational commitment and salesperson job performance: 25 years of research. Journal of Business Research, 58, 705-714. https://doi.org/10.1016/j.jbusres.2003.10.004

Jaramillo, F., Mulki, J. P., \& Solomon, P. (2006). The role of ethical climate on salesperson's role stress, job attitudes, turnover intention, and job performance. Journal of Personal Selling \& Sales Management, 3, 271-282. https://doi.org/10.2753/PSS0885-3134260302

Jayaratne, R. T. (1993). The antecedents, consequences, and correlations of job satisfaction. In R. T. Golombiewski (Ed.), Handbook of organizational behavior (pp. 111-140). New York: Marcel Dekker.

Kim, W. C., \& Brymer, R. A. (2011). The effects of ethical leadership on manager job satisfaction, commitment, behavioral outcomes, and firm performance. International Journal of Hospitality Management, 30, 1020-1026. https://doi.org/10.1016/j.ijhm.2011.03.008

Locke, E. A. (1976). The Nature and Causes of Job Satisfaction. In Handbook of Industrial and Organizational Psychology (pp. 1297-1350). Chicago: Rand McNally.

Malik, M. E., Nawab, S., Naeem, B., \& Danish, R. Q. (2010). Job satisfaction and organizational commitment of university teachers in Public sector of Pakistan. International Journal of Business and Management, 5(6), 17-26. https://doi.org/10.5539/ijbm.v5n6p17

Meyer, J. P. and Allen, N. J. (1991). A three-component conceptualization of organizational commitment. Human Resource Management Review, 1(1), 61-90. https://doi.org/10.1016/1053-4822(91)90011-Z 
Meyer, J. P., Allen, N. J., \& Smith, C. A. (1993). Commitment to organizations and occupations: Extension and test of a three-component conceptualization. The Journal of Applied Psychology, 78(4), 538-551. https://doi.org/10.1037/0021-9010.78.4.538

Meyer, J. P., \& Allen, N. J. (1997). Commitment in the Workplace: Theory, Research and Application. Thousand Oaks, CA: Sage.

Moorman, R. H., Niehoff, B. P., \& Organ, D. W. (1993) Treating employees fairly and organizational citizenship behavior: sorting the effects of job satisfaction, organizational commitment, and procedural justice. Employee Responsibilities and Rights Journal, 6(3), 209-225. https://doi.org/10.1007/BF01419445

Mulki, J.P., Jaramillo, F., Locander, W.B. (2006). Effects of ethical climate and supervisory trust on salesperson's job attitudes and intentions to quit. Journal of Personal Selling \& Sales Management, 26 (1), 19-26. https://doi.org/10.2753/pss0885-3134260102

Okpara, J. O., \& Wynn, P. (2008). The impact of ethical climate on job satisfaction, and commitment in Nigeria. Journal of Management Development, 27(9), 935-950. https://doi.org/10.1108/02621710810901282

Sharma, D., Borna, S., \& Stearns, J. M. (2009). An Investigation of the Effects of Corporate Ethical Values on Employee Commitment and Performance: Examining the Moderating Role of Perceived Fairness, Journal of Business Ethics, 89, 251-260. https://doi.org/10.1007/s10551-008-9997-4

Shore, L. M., \& Wayne, S. J. (1993). Commitment and employee behavior: comparison of affective commitment and continuance commitment with perceived organizational support. Journal of Applied Psychology, 78, 774-780. https://doi.org/10.1037/0021-9010.78.5.774

Smith, C. A., Kendall, L. M., \& Hulin, C. L. (1969). The Measurement of Satisfaction in Work and Retirement: A Strategy for the Study of Attitudes: Rand McNally, Chicago.

Sommer, K. L., \& Kulkarni, M. (2012). Does constructive performance feedback improve citizenship intentions and job satisfaction? The roles of perceived opportunities for advancement, respect, and mood. Human Resource Development Quarterly, 23(20), 177201. https://doi.org/10.1002/hrdq.21132

Spector, P. E. (1997). Job satisfaction: Application, assessment, courses, and consequences: Sage Publications, Inc.

Trading Economics (2016). Unemployment Rate in BiH. Retrieved on July 11, 2016 form website: http://www.tradingeconomics.com/bosnia-and-herzegovina/unemployment-rate.

Trevino, L. K., Butterfield, K. D., \& McCabe. K. L. (1998). The ethical context in organizations: influence on employee attitudes and behaviors. Business Ethics Quarterly, 8: 447-476. https://doi.org/10.2307/3857431

Tsai, M., \& Huang, C. (2008). The Relationship among Ethical Climate Types, Facets of Job Satisfaction, and the three components of organizational commitment: a study of nurses in Taiwan. Journal of Business Ethics, 80, 565-581. https://doi.org/10.1007/s10551-007-9455-8

Victor, B., \& Cullen, J. B. (1987). A theory and measure of ethical climate in organizations. In: Frederick WC and Preston LE (eds) Business ethics: research issues and empirical studies (pp. 77-97). Greenwich: JAI Press, Inc.

Victor, B., \& Cullen, J. B. (1988). The organizational bases of ethical work climates. Administrative Science Quarterly, 33: 101-125. https://doi.org/10.2307/2392857 